К итогам научной конференции «Фундаментальное знание: диалог российских и буддийских ученых»

\title{
Д.И. ДУБРОВСКИЙ
}

Институт философии РАН, Москва, Россия

Дубровский Давид Израилевич - доктор философских наук, профессор, главный научный сотрудник Института философии РАН.

ddi29@mail.ru

Участники Круглого стола: Тэло Тулку Ринпоче, К.В. Анохин, Ю.И. Александров, Д.И. Дубровский, В.Г. Лысенко, А.А. Терентьев, Т.В. Черниговская, М.В. Фаликман и др.

Цитирование: ДУБРОВСКИЙ Д.И. (2018) Буддизм и наука. Круглый стол. Москва, Институт философии РАН, 31 октября 2017 г. // Философские науки. 2018. № 3. С. 42-80.

DOI: $10.30727 / 0235-1188-2018-3-42-80$.

Проблема сознания приобретает все большую актуальность и остроту в связи с нарастанием глобального кризиса нашей потребительской цивилизации. Разработка этой проблемы становится, без преувеличений, первостепенной, стратегической задачей научного познания. Для этого требуется более глубокое осмысление теоретико-методологических вопросов исследования сознания, объединение усилий многих дисциплин естественнонаучного и социогуманитарного профиля, а тем самым решение вопросов междисциплинарного характера. Важное значение при этом имеет понимание тесной связи философских и научных аспектов проблемы, учет различных философских направлений и подходов в изучении сознания, сопоставление опыта западной и восточной философской мысли. В этом отношении большую ценность для современных научных исследований представляет тысячелетний опыт философии буддизма в области медитативных практик, осмысления психологических, феноменологических и эпистемологических вопросов изучения сознания, многочисленные труды Его Святейшества Далай-ламы, который не 
только призывает ученых к сотрудничеству, но и активно его организует.

Ярким примером этого явилась научная конференция, материалы которой опубликованы в данном номере журнала. Она выявила те весьма значительные ресурсы изучения сознания, которые могут быть использованы в ходе сотрудничества российских и буддийских ученых. Конференция для нас, российских ученых, была весьма интересной и плодотворной. Можно считать, что намеченный диалог по проблеме сознания успешно состоялся. Разумеется, обнаружились и существенные расхождения в трактовке ряда феноменов психической деятельности человека, в философских объяснениях трудности в соотнесении западной и буддийской терминологии в описании явлений сознания. Однако эти расхождения не препятствуют созданию общей концептуальной платформы, что требует, конечно, дальнейшего осмысления. Поэтому было решено провести Круглый стол, специально посвященный этому кругу вопросов, материалы которого публикуются ниже. В них на основании стенограммы воспроизведено содержание выступлений и отдельных замечаний участников Круглого стола с некоторыми комментариями.

К.В. Анохин (модератор Круглого стола): Это было очень необычное событие, и не только потому, что оно первое, но и потому, что оно было необычно по содержанию.

Тэло Тулку Ринпоче, почетный представитель Его Святейшества Далай-ламы в России, Монголии и странах СНГ, верховный лама (шаджин-лама) Республики Калмыкия: Конференция «Фундаментальное знание: диалог российских и буддийских ученыху стала для всех ее участников поистине судьбоносным событием, воспоминание о котором по сей день рождает в наших сердцах целую гамму эмоций. Разумеется, диалог между представителями современной науки и буддийскими учеными-философами во главе с Его Святейшеством Далай-ламой - начинание отнюдь не новое. Этой инициативе духовного лидера тибетского буддизма уже 30 с лишним лет. Однако впервые в диалог с Его Святейшеством Далай-ламой вступили ученые из России. Могу с уверенностью сказать, что вначале в их отношении к происходящему присутствовала изрядная доля скептицизма. Но, с другой стороны, в буддизме всегда приветствовали скептицизм и сомнения как метод исследования действительности.

Первая конференция, состоявшаяся в августе в Дели, на мой взгляд, открыла перед нами множество дверей, множество возможностей для дальнейшего общения и сотрудничества, для раз- 
столе были в какой-то мере намечены, обозначены те конкретные задачи, которые могут быть предметом нашего сотрудничества с Его Святейшеством Далай-ламой и буддийскими учеными. Ряд таких задач отчетливо поставлен в их трудах, касающихся освоения результатов медитативных практик. Эти результаты позволяют, например, более точно выделять и определять различные феномены сознания, что может служить целям современным исследований сознания с позиций нейронауки. Там требуется более четкое описание и ограничение психических явлений, которые служат объектом установления их нейродинамических коррелятов. Важное значение опыт буддизма имеет в области развития способности более эффективного управления собственным сознанием, преодоления его устойчивых негативных интенций. Этот опыт может быть использован и социогуманитарными дисциплинами, особенно когда ставятся вопросы образования и воспитания. Безусловно, конкретная программа совместных исследований должна быть тщательно продумана и согласована. Мы уверены, что наш диалог с буддийскими коллегами будет в этом направлении продолжен.

\section{«BUDDHISM AND SCIENCE» Round Table \\ Moscow, Institute of Philosophy, Russian Academy of Sciences, October 31, 2017. \\ To the Results of the Scientific Conference «Fundamental Knowledge: the Dialogue of Russian and Buddhist Scientists»}

\section{D.I. DUBROVSKY}

Institute of Philosophy, Russian Academy of Science, Moscow, Russia

Dubrovsky, David - D.Sc. in Philosophy, Professor, Main Research Fellow at the Department of the Epistemology, Institute of Philosophy, Russian Academy of Sciences, Moscow, Russia.

ddi29@mail.ru

Participants of the Round Table: Telo Tulku Rinpoche, K.V. Anokhin, Yu.I. Alexanrov, T.V. Chernigovskaya, Dubrovsky, M.V. Falikman, V.G. Lysenko, A.A. Terentiev, et al.

Citation: DUBROVSKY D.I. (2018) "Buddhism and Science". Round Table. Moscow, Institute of Philosophy, Russian Academy of Sciences, October 31, 2017. In: Philosophical Sciences. 2018. Vol. 3, pp. 42-80.

DOI: $10.30727 / 0235-1188-2018-3-42-80$. 